\title{
飽和砂地盤上の盛土の地震時安定性 に関する遠心力模型振動実験
}

\author{
風間基樹 ${ }^{1} \cdot$ 稲富隆昌 $^{2} \cdot$ 飯塚栄寿 ${ }^{3} \cdot$ 永吉貴行 $^{4}$ \\ ${ }^{1}$ 正会員 博士(工学) 東北大学助教授 大学院工学研究科土木工学専攻(テ980-77 仙台市青葉区荒巻字青葉) \\ ${ }^{2}$ 正会員 工博 運輸省港湾技術研究所 構造部 部長 ( \\ 3学生員 運輸省港湾技術研究所 構造部 構造振動研究室 研究員 ( T239 横須賀市長瀬3-1-1) \\ ${ }^{4}$ 正会員 五洋建設株式会社 九州支店（テ810 福岡市中央区警固1-12-11）
}

\begin{abstract}
飽和砂地盤上の盛土の地震時安定性に関する遠心力模型振動実験を実施した．実験は模型縮尺が1/37.5(正 弦波加振), $1 / 50$ (正弦波および地震波加振)の $2 つ の$ 模型を用いた合計 3 断面のステージテストである. 残留変形 量, 加速度・間隙水圧応答を相似則により実物換算して考察するとともに, 加速度・間隙水压を考虑した静 的安定計算を行った. 主な結論は以下のとおりである. (1)2つの異なる縮尺でモデル化した盛土の実物換算 残留変形量は良い対応を示した. (2)飽和砂地盤上の盛土の安定性は基礎地盤の液状化に影響される. 残留変 形の生じた境界面は円弧状となったが，滑り土塊は剛体的に挙動せず流動変形的な破壊モードを示した. (3) 盛土および基礎地盤の加速度・間隙水圧を考虑した安定解析は実験結果をうまく説明することができた.
\end{abstract}

Key Words: shaking table test, centrifuge, similitude, slope stability, liquefaction, saturated sand

\section{1. まえがき}

都市臨海部のゼロ・メートル地帯の海岸保全施設 である護岸・堤防が地震により破壊した場合, その 背後地域は壊滅的被害を受ける.このような低地域 を地震災害から守るため, 既存護岸を幅広くした緩 傾斜型の高規格な堤体の整備が進められている.

現在, 斜面や盛土地盤の安定性は, 円形すべり法 あるいは直線すべり法によって検討されている.し かし, すべり破壊に対する地震力の効果は, 液状化 や地盤中の地震応答の評価などに不明な点が多いた め考慮されておらず, 常時の安定計算を以って代用 されているのが現状である1). すなわち, 常時の計算 での安全率1.3を適用することによって, 地震時に付 加的に作用する外力を考慮している.

盛土や斜面が地震によって崩壊した事例は, 今ま で数多く報告され，その被害事例解析が行われてき た 2) 4). これらの研究により, 基礎地盤の3次元的構 造, 材料構成, 盛土の傾斜角や液状化層の底面勾配 などによって実際の盛土の破壊形態が分類され, 被 害の主な原因が振動の増幅や液状化であることが認 識されてきた. 釧路沖(), 北海道南西沖6), 北海道東

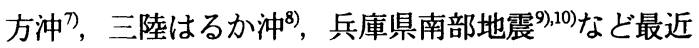

の地震災害においても，河川堤防・宅地盛土・鉄道 盛土などの斜面崩壊の事例が多く報告されており, 設計法の高度化が期待されている.

斜面の地震時安定性のメカニズムを検討するため の一つのアプローチとして, 模型振動実験がある.

Uwabe et.al ${ }^{11)}$ は，大型振動台を用いて層厚 $1.1 \sim 1.2 \mathrm{~m}$ の飽和砂地盤上の高さ1.1 1.3mの盛土の破壊実験を 行った.これによると, 震度と過剩間隙水圧を考慮 した円形すべり解析で盛土の破壊が説明できるとし ている. また, 古賀ら ${ }^{12)}$ は高さ $20 \mathrm{~cm}$ 盛土を, 長さ $250 \mathrm{~cm}$ 深さ $40 \mathrm{~cm}$ の液状化地盤上に作成し振動実験を 行い, 盛土の地震時安定性を種々の動的強度の考え 方を用いて検討している.

このような通常の重力場で行なわれる大型実験の ほかに，最近では遠心力載荷装置を用いた振動実験

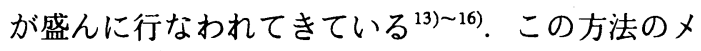
リットは, 実物とほぼ同じ応力状態を模型に再現で きる点である. その意味で, 粘性土地盤を対象とし た斜面の静的安定問題は遠心力載荷装置を用いた実 験の第一の研究対象となっている ${ }^{17)}$. 一方, 砂地盤の 液状化や永久変形量の実験室レベルでの研究に関し ても, 砂のダイレイタンシー特性や残留強度が拘束 圧に大きく依存すると考えられていることから，遠 
a）飽和砂層上の盛土の想定実物断面

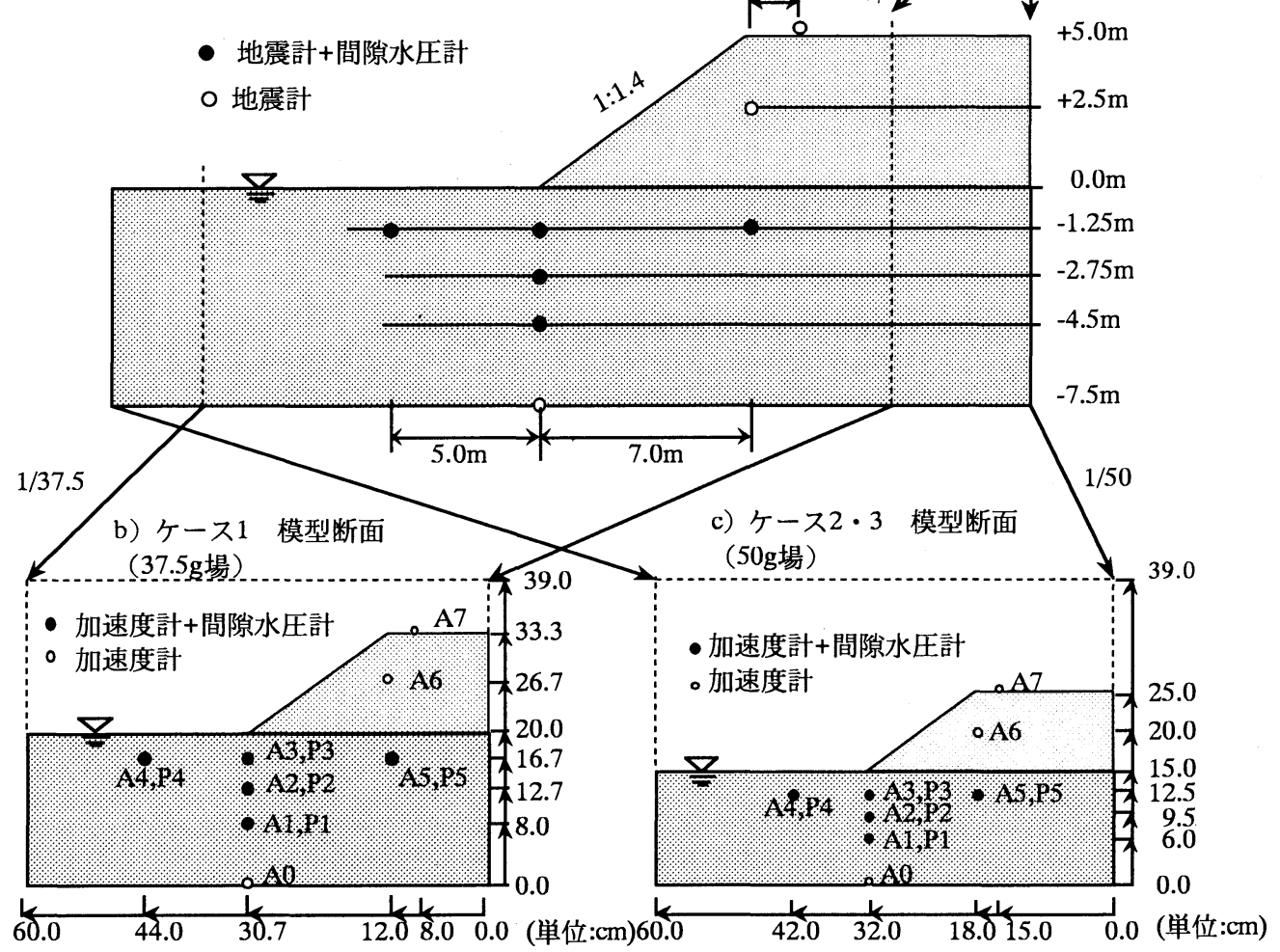

図-1 実物想定断面・模型断面およびセンサーの配置

心力場で実験することの意義が大きいと考えられて いる. このような動向の中で, 斜面の地震時安定性 屯, 最近の中心的な研究対象となってきているが, 手法自体が十分に成熟していない段階であり，結果 の蓄積に待つところが大きい.

古関ら ${ }^{13)}$ は, 液状化地盤上の堤体の地震時安定に関 して同一規模の盛土を想定し, 30gおよび50g場の遠 心力場で振動実験を実施した. 両者の結果を比較し たところ, 沈下量に関しては良い一致が得られてい るが, 液状化そのものに関しては, 模型の作成方法 や加振履歴に微妙に影響されることを示した. 実験 においては，堤体を粘性土混じりの砂で作成してお り, 破壊モードは基礎地盤の液状化による堤体部の 沈下であった. 古関らの研究の他, 堤体や斜面の地 震時安定性に関する遠心振動実験が行われている が, モデル化の範囲・境界条件, 堤体構成材料の違 いによって，その破壊形態はかなり異なったものと なっている.

本研究では, 液状化地盤上での盛土の地震破壊の メカニズムを知る目的で, 遠心力模型振動実験を実 施した結果を報告する. 実験の対象として想定した 実物規模は, 盛土高さ $5 \mathrm{~m}$ 基礎地盤層厚7.5mである.
また，相似則の妥当性を検討するため，1/37.5および 1/50の二つの模型縮尺を使用した．古関らの実験と異 なる点は, 液状化地盤上にそれと同種の摩擦性材料 の盛土を持つ場合を想定していることである.すな わち，盛土は偏った上載荷重であると同時に盛土自 身も大きな被災変形を受けることになる，また，実 験の最中にCCDカメラにより破壊状況を録画し, 盛 土の変形を遠心場でなるべく定量的にとらえるよう に努力した.

\section{2. 実験方法}

遠心力振動実験は, 有効半径 $3.8 \mathrm{~m}$ の港湾技術研究 所の遠心力載荷装置を用いて実施した ${ }^{18)}$. また, 振動 実験に用いた振動台は同所で開発された油圧式振動 台である ${ }^{19}$.

\section{（1）想定した実物盛土と実験ヶース}

図-1a)は，遠心力振動実験に用いた模型の断面およ び実物として想定した盛土を示したものである．層 厚 $7.5 \mathrm{~m}$ の飽和地盤上に高さ $5 \mathrm{~m}$, 法面勾配 $1: 1.4$ の盛 土を想定している. 飽和砂地盤上の盛土模型は, 内 
表-1 実験ケース一覧表

\begin{tabular}{|c|c|c|c|c|c|c|c|c|c|c|c|c|c|}
\hline ケース & $\begin{array}{l}\text { 遠心 } \\
\text { 加速度 }\end{array}$ & \begin{tabular}{|c|} 
密度 \\
(乾燥部)
\end{tabular} & \begin{tabular}{c|} 
密度 \\
(飽和部)
\end{tabular} & 相対密度 & $\begin{array}{l}\text { シリコン } \\
\text { 油の粘性 }\end{array}$ & 入力波形 & 振動数 & 波数 & \multicolumn{5}{|c|}{ 加振ステージ番号/最大加速度 $(\mathrm{Gal})$} \\
\hline No. & $(\mathrm{G})$ & $\left(\mathrm{g} / \mathrm{cm}^{3}\right)$ & $\left(\mathrm{g} / \mathrm{cm}^{3}\right)$ & $(\%)$ & (cs) & & $(\mathrm{Hz})$ & & 1 & 2 & 3 & 4 & 5 \\
\hline 1 & 37.5 & 1.48 & 1.91 & 51 & 55 & 正弦波 & 2.0 & 20 & 27 & 105 & 159 & 381 & - \\
\hline 2 & 50.0 & 1.47 & 1.90 & 48 & 80 & 正弦波 & 2.0 & 20 & 48 & 108 & 160 & - & - \\
\hline 3 & 50.0 & 1.48 & 1.92 & 52 & 80 & 八戸波 & - & - & 21 & 40 & 74 & 228 & 272 \\
\hline
\end{tabular}

表-2 遠心振動実験の相似則

\begin{tabular}{|c|c|}
\hline 項目(模型/実物) & 相似比 \\
\hline 長さ & $1 / \mathrm{n}$ \\
\hline ひずみ & 1 \\
\hline 加速度 & $\mathrm{n}$ \\
\hline 時間 & $1 / \mathrm{n}$ \\
\hline 振動数 & $\mathrm{n}$ \\
\hline 応力 & 1 \\
\hline 間隙水压 & 1 \\
\hline 透水係数 & $1 / \mathrm{n}$ \\
\hline
\end{tabular}

寸法が幅 $60 \mathrm{~cm}$, 奥行き $20 \mathrm{~cm}$, 高さ $39 \mathrm{~cm}$ の剛な振動箱 に作製した。図-1b)は，遠心加速度が37.5gのケース 1，図-1c)は，遠心加速度が50gのケース $2 \cdot 3$ の模型断 面図である。図-1には，加速度計および間隙水圧計 の設置位置も併せて示した. なお，このように同一 サイズの振動箱で模型を製作しているため，模型地 盤の物性に関係する深さ方向の実物寸法は一致して いるが，対応する実物の幅，奥行き方向の寸法は二 つのケースで一致していない. なお，モデル化の範 囲に対する影響を少なくするため，模型の寸法は前 もって静的安定計算によってその破壊形状を想定し て決定している.

表-1にここで報告する実験ケースの一覧を示す. ケース1・2は，模型縮尺の影響，ケース $2 \cdot 3$ は加振 波形の影響を明らかにする目的で実施したものであ る. 実験は，表に示すように加振加速度を順次上げ て実施するステージテストとした。なお，表-2に遠 心力場の振動実験の相似比 ${ }^{20)}$ を示すが, 表-1の振動 数, 加振最大加速度は実物換算值で示した. 以降, 実験結果は，特に断らない限り表-2の相似則に基づ いて実物に換算して表わした.

\section{（2）模型の作成方法}

模型地盤の材料は，豊浦標準砂および相似則にあ うような透水係数を得るよう粘度調整したシリコン オイル（37.5g模型で $55 \mathrm{cs}, 50 \mathrm{~g}$ 模型で $80 \mathrm{cs})$ である 20). 飽和砂地盤上の盛土の模型は, まず振動箱のポー ラスストーン製の底板上に気乾状態の砂地盤・盛土 を4段重ねの $840 \mu$ フルイを通過させながら自由落下
させて製作した.このとき，模型の変形を視覚的に 観察するため, 赤色に着色した標準砂柱を振動箱の ガラス面と接して模型地盤に建て込んだ21). 地盤を 飽和させるための手順は次のとおりである。ま ず，模型地盤および間隙流体としてのシリコンオ イルを脱気する. 次に, 脱気状態のまま, ポーラ スストーンの下からシリコンオイルを水頭差だけ で浸透させ，地盤を飽和させる。このようにして 製作した地盤の密度, 相対密度等を, 表-1に示 す.なお，豊浦標準砂を用いた既往の研究成果 ${ }^{22)}$ を参考にして相対密度から内部摩擦角を推定する と, どのケースも約 $36.5^{\circ}$ となった.

\section{3. 実験結果および考察}

\section{(1) 最大加速度応答}

図-2は, それぞれのケースの砂層, 盛土の最大応 答加速度を加振レベル毎に示したものである．なお 正弦波加振の加速度の值は応答波形の後半部分の振 幅の平均値とした.このように地震波の場合は最大 值, 正弦波の場合には加振後半部分の平均振幅とし たのは, 地震波実験の場合にはしばしばその最大值 で議論されることが多いこと，正弦波の場合には振 動が終了する直前が最も定常な状態に近いと考えら れるからである. ケース1と2を比較すると, 両ケ一 スとも，A4を除く砂層，盛土の加速度は，基盤の加 速度が150Galに達するまでは, 基盤加速度に比例し て大きくなっている. ケース1の基盤加速度379Galの 実験では，A2・A3の応答加速度は，基盤加速度が 100〜150Galのそれとほぼ同じで，基盤加速度より小 さく約半分となっている. また，A4の海側地盤の加 速度も100Gal以下と小さい. 一方, 盛土法肩直下A5 の応答加速度は，同じ高さの海側・法尻部のそれよ り大きい.このような加速度分布から，海側地盤は 低加速度レベルから地盤が剛性低下し，また斜面の 法尻直下の地盤は，基盤加速度が150Gal以上になる と地盤の剛性低下が顕著に現れたと考えられる. 一 方盛土法肩直下の地盤は盛土によって有効上載圧が 大きくなっているため, 地盤の剛性低下の程度が小 さかったと考えられる. 

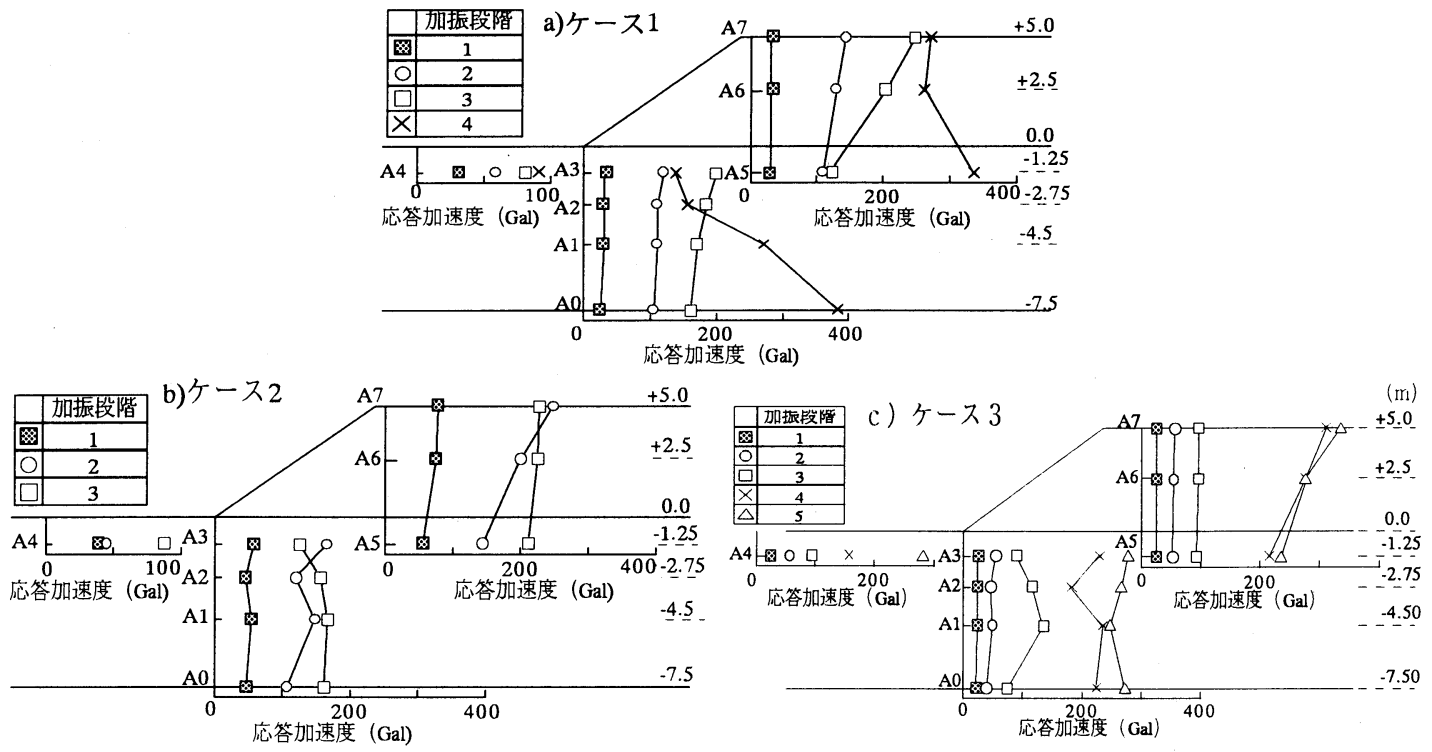

図-2 各実験ケースの最大加速度分布

a)ケース 1
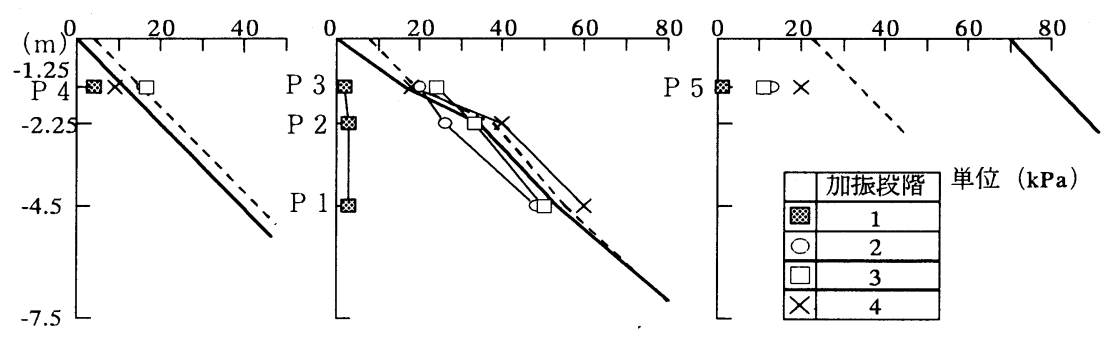

b)ケース 2
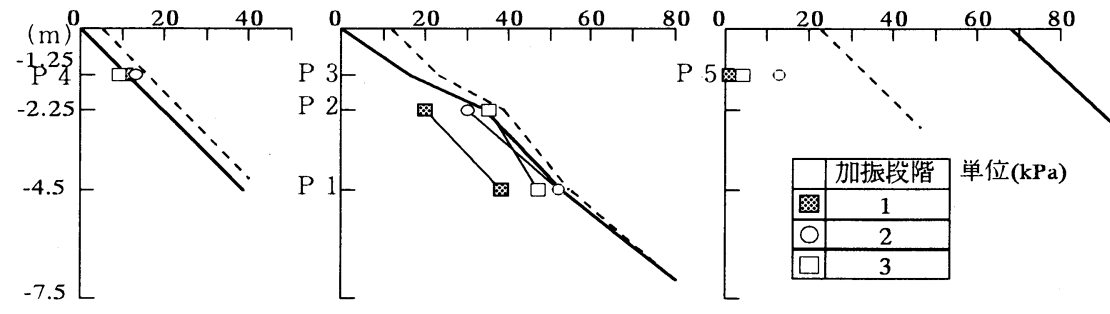

c)ケース 3
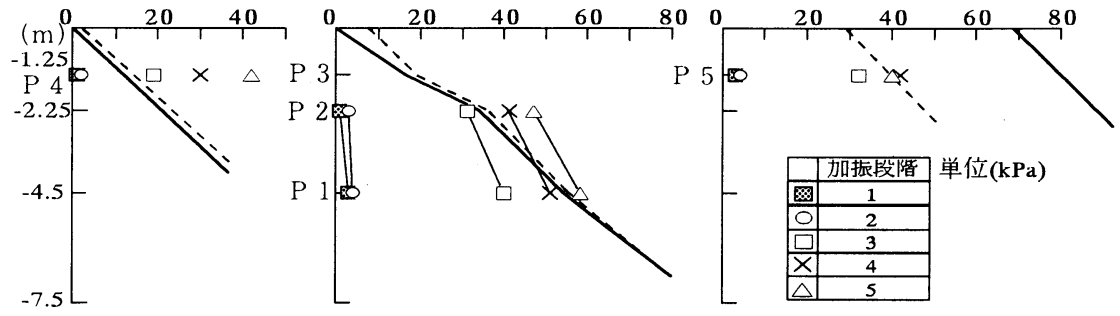

図-3 各実験ケースの間隙水圧分布

（2）過剩間隙水圧応答

図-3は，それぞれのケースの飽和砂層の過剩間隙水 圧を示したものである．図-4に示すように間隙水圧の 時刻歴には，加振中の振動成分が見られるが，図-3に 示す過剩間隙水圧の值は，正弦波実験の場合には正弦 波20波の振動が終了した時点の水圧とし, 地震波実験
の場合には最大値とした．この取り扱いは前節で述 べた理由による.また，図中の太実線は初期有効上 載圧であり，地盤を飽和水平地盤と盛土部分に分け て考えたときの鉛直有効応力の合算值である．盛土 部分の上載圧は, 盛土を上載荷重であると仮定し て，オスターバーグの鉛直地中応力の影響值を用い 
a)ケース 1 加振段階 4
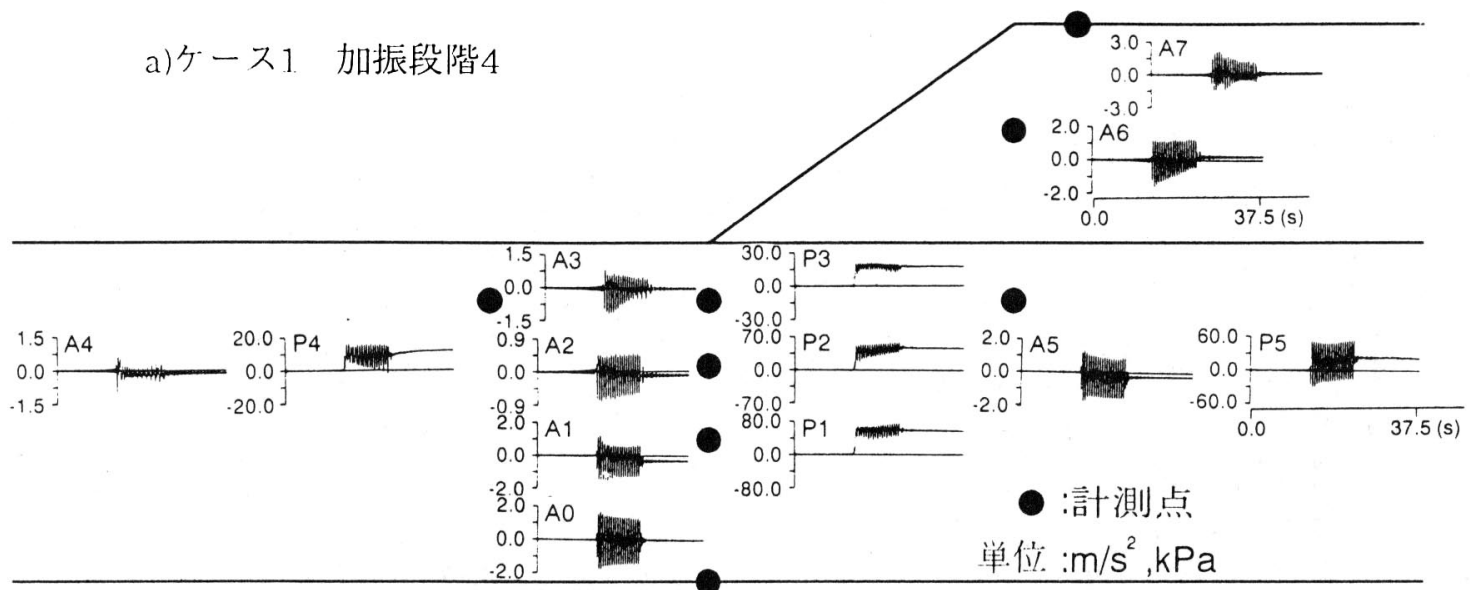

b)ケース2 加振段階3

: 計測点

単位 $: \mathrm{m} / \mathrm{s}^{2}, \mathrm{kPa}$

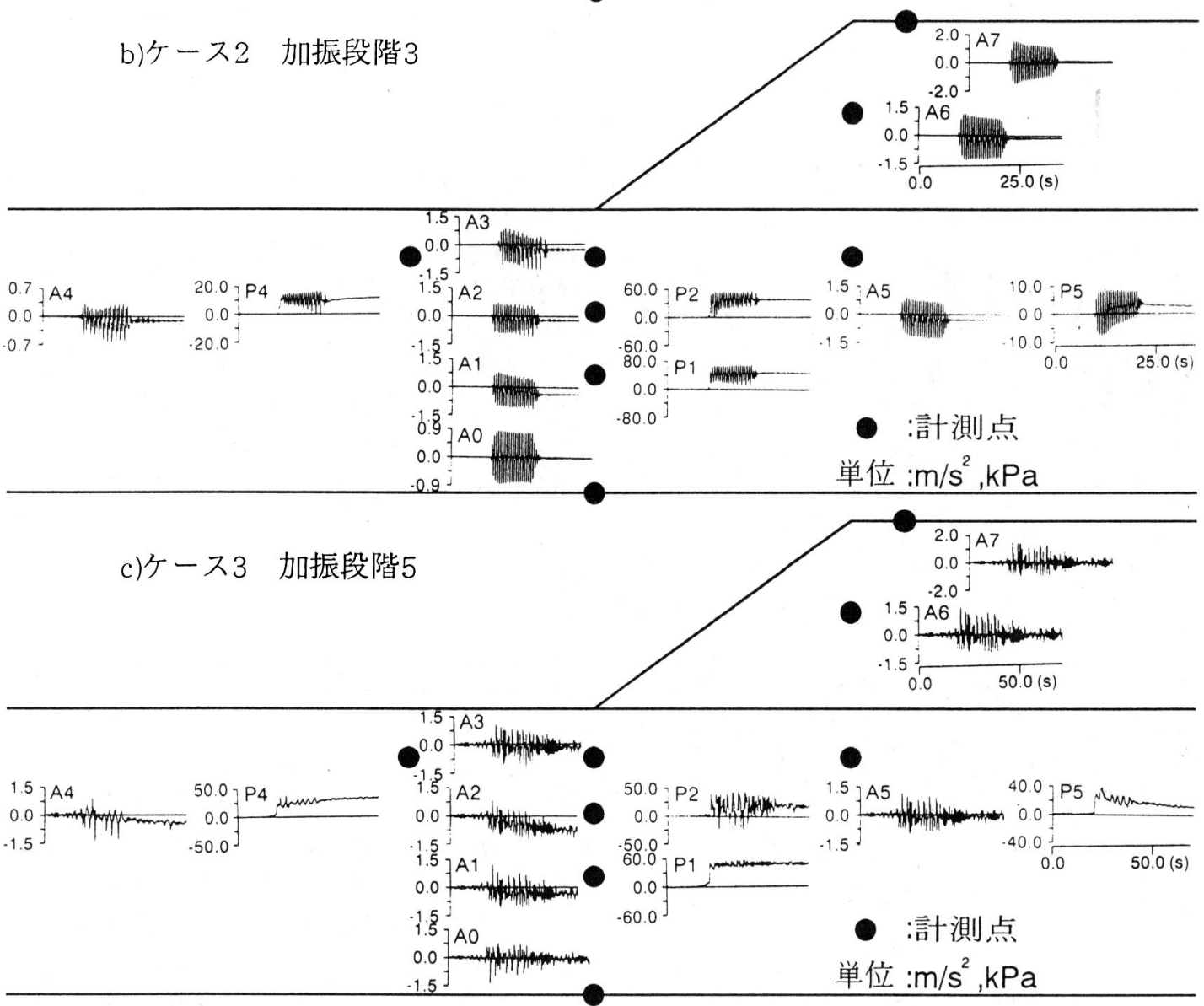

図-4 ケース毎の各加振段階での加速度・過剩間隙水圧の時刻歴（横軸は実験のスケール）

て求めた砂層内の鉛直応力である．また，点線は盛 土・飽和砂層の最終変形状況から推定した同様の有 効上載圧である. なお，ケース $2 \cdot 3$ の間隙水圧計 $\mathrm{P} 3$ は, 極端に小さな值を示していたので, デー夕は図 示していない.

ケース 1 ・2の法尻部および海側地盤部の間隙水圧
は，加振レベルが増加するにともなって，有効上載 圧に漸近し, 液状化が発生している。一方, 盛土法 肩直下の間隙水圧は，有効上載圧比で概ね $50 \%$ 以下 である.これら間隙水圧の結果は, 大きな加速度レ ベルで加速度応答が低下するという実験結果を裏づ けるものと言える. また, ケース3の水圧応答は, 正 
P0 $(0.00 \cdot 10.00)$

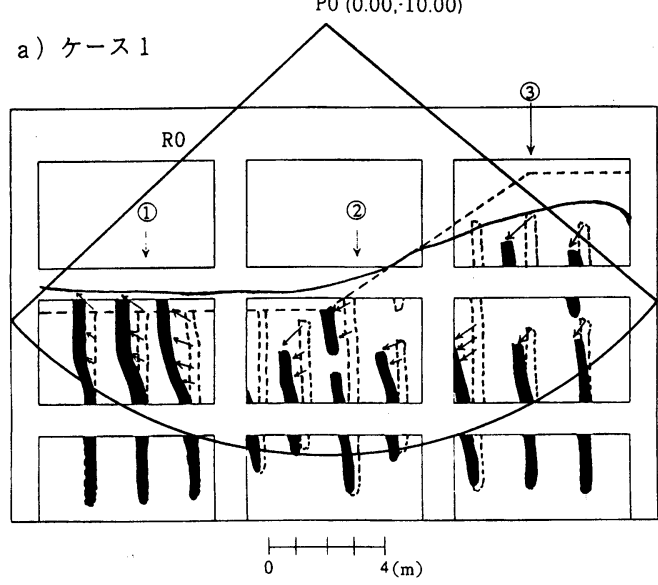

b) ケース 2

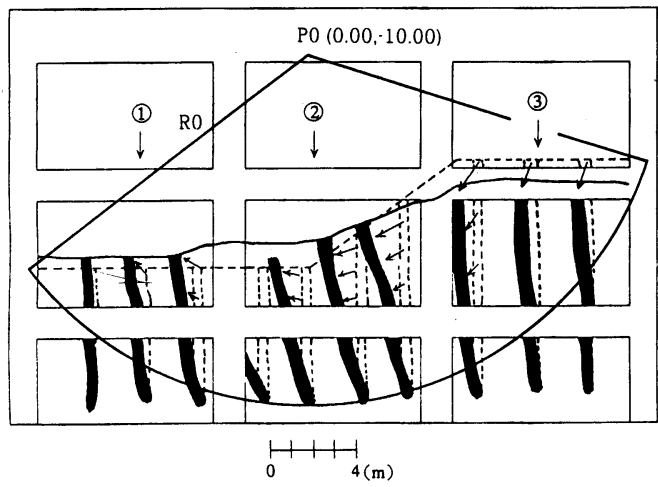

c) ケース 3

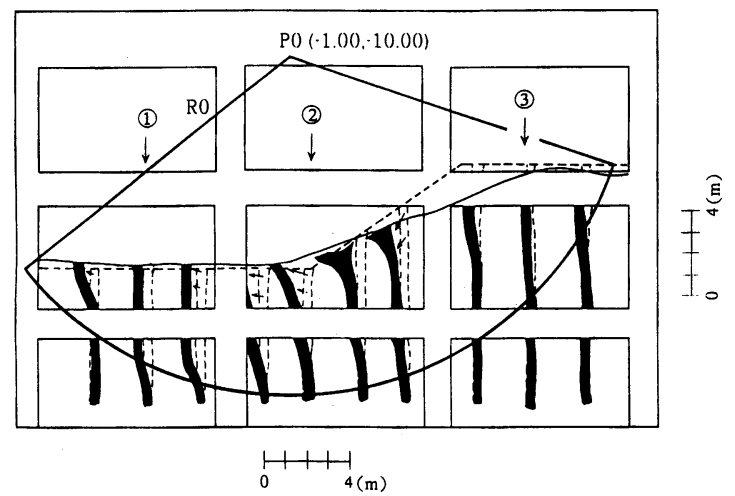

図-5 最終変形状況および残留変形が生じた境界と思わ れる円弧

弦波加振の場合より大きくなっているが, 短周期の 波に応答した振動成分を拾ったものである．また，

ケース 3 海側地盤の間隙水圧応答は上載圧よりも2倍 ほど大きくなっているが, 振動成分に加えてセン サーの沈下が起こったためであることが，実験後の 解体で確認されている.
（3）加速度および間隙水圧の時刻歴応答

図-4は，ケース毎の最終加振段階の過剩間隙水圧 （P1〜P5） と加速度の時刻歴を示したものである. 加振中の加速度応答を見ると，のり尻直下部A3で は, 液状化の発生によって加速度応答が小さくな る. また，加速度計自身が傾斜したために，加速度 值が加振後も残留している. さらに，海側A4および 法尻直下A3の加速度応答にはサイクリックモビリ ティと見られるスパイク状の加速度応答が認められ る. 一方, 加振中の間隙水圧は，振動成分之漸増成 分に分けられるが，海側(P4)および法尻直下(P1-3)で は，盛土法肩直下P5に比較して漸増成分が支配的で ある．また，水圧の消散過程を検討したところ，実 物スケール加振時間10秒に対して上層ほど消散が遅 く, P4では, 約2分間有効上載圧とほぼ等しい高い水 圧の保持が認められた。一方，盛土直下の過剩間隙 水圧比は小さく, 消散速度も速くなっていた.

なお，ここに示した時刻歴はすへて最終加振段階 のものであり，これ以前の加振段階での加速度計の 傾斜に伴う残留加速度や間隙水圧計の沈下に伴う残 留間隙水圧は小さいと見なし，これらに関する補正 は行っていない，すなわち，前の加振段階での残留 值が少し残っている場合でも，その最終值を次の加 振段階での初期値としている.

\section{(4) 残留変形}

図-5は，ガラス面を通して見たそれぞれのケース の砂層・盛土の最終変形状況である. 図中には, 残 留変形を生じた部分と生じていない部分の境界と見 なせる円弧も示した．円弧の中心座標は，法尻を原 点とする実物換算座標である．また，加振前の形状 は点線で示すとおりであり, 盛土の中の黒塗の部分 は模型の変形を観察するために建て込んだ赤色砂柱 を示す．ここで，ガラス補強用のアルミ製格子中に も実線・波線を示すが，この部分は実験後の計測か ら求めたものである.なお，(1)（3)は後述する盛土 の加振段階每の変形を観察した位置を示す.

模型地盤の変形量は盛土の斜面付近で大きく， か つ地表面に近いほど大きい，その最終変形量は50〜 $200 \mathrm{~cm}$ となっている. また, 残留変形を生じた部分と 生じていない部分の境界面は，図中に示すようにほ ぼ円弧状の形となることから，円形滑り的な破壊 モードと考えることもできる. しかし，図中に示し たベクトル図を見ると，表層ほど変形量が大きく なっており，円弧で囲まれた滑り土塊が剛体的に滑 り面に沿って変形したのではないこともわかる.こ のような変形はむしろ流動的な変形とみなせる.

盛土模型の変形はこの最終変形の他に, $\mathrm{CCD} \times$ 


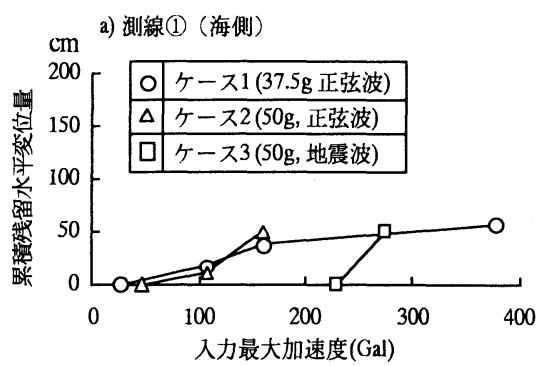

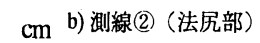

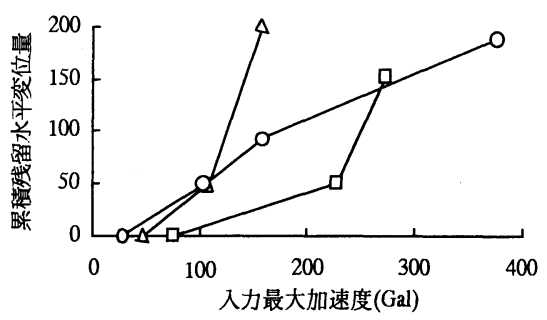

$\mathrm{cm}$ c) 測線(3)（盛土部）

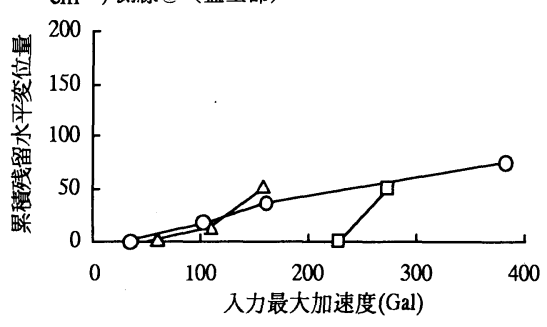

図-6 CCDカメラで計測した残留変形量

ラによっても観察した，図-6は，VTRに収録した画 像から各加振後に図-5に示した(1)〜 (3)の地表面の赤 色砂柱の水平残留変位量を読み取り，それを入力最 大加速度に対して示したものである．ケース1・2の 残留変形は, 共に入力加速度が100Gal付近から生 じ，その変位量もほぼ同じである。このように縮尺 の異なるケースを実物換算した結果が同じであるこ とは，ここで用いた縮尺 $1 / 50 〜 1 / 37.5$ 範囲では残留 変形に関して相似則が成立していると言える。 ま

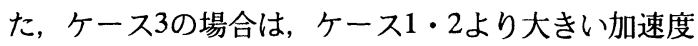
レベルにならないと変形が生じていない。 したがっ て地震波加振の外力は, 正弦波のそれより小さく, 残留変形に関して言えば, 正弦波20波と等しい残留 変位を生じさせるためには地震波の場合約2倍の最大 加速度が必要となることがわかる.

\section{4. 円形滑り解析}

斜面の安定解析には, 従来から円形すべりあるい は複合すべり面を考えた極限安定解析が用いられて きた ${ }^{23)}$. 地震時の安定に関しては, 有限要素法などの
表-3 安定解析に用いた地震力一覧表（震度）

\begin{tabular}{|c|c|c|c|c|c|c|}
\hline ケース & 加振段階 & C 1 層 & C 2 層 & C 3 層 & D 層 & E F 層 \\
\hline \multirow{4}{*}{1} & 1 & 4.0 & 2.0 & 1.0 & 3.0 & 3.0 \\
\cline { 2 - 7 } & 2 & 16.0 & 20.0 & 13.0 & 26.0 & 48.0 \\
\cline { 2 - 7 } & 3 & 17.0 & 24.0 & 11.0 & 33.0 & 50.0 \\
\cline { 2 - 7 } & 4 & 9.0 & 18.0 & 20.0 & 40.0 & 60.0 \\
\hline \multirow{4}{*}{2} & 1 & 11.0 & 1.0 & - & 20.0 & 38.0 \\
\cline { 2 - 7 } & 2 & 13.0 & 13.0 & - & 30.0 & 52.0 \\
\hline \multirow{4}{*}{3} & 3 & 9.0 & 4.0 & - & 35.0 & 47.0 \\
\cline { 2 - 7 } & 1 & 1.0 & 3.0 & - & 1.0 & 3.0 \\
\cline { 2 - 7 } & 2 & 2.0 & 4.0 & - & 3.0 & 4.0 \\
\cline { 2 - 7 } & 3 & 19.0 & 32.0 & - & 31.0 & 40.0 \\
\cline { 2 - 7 } & 4 & 30.0 & 42.0 & - & 41.0 & 51.0 \\
\cline { 2 - 7 } & 5 & 42.0 & 40.0 & - & 47.0 & 58.0 \\
\hline
\end{tabular}

数値解析で直接的に解析してしまう方法 ${ }^{24)}$ や有限要素 法により地震力を算定した後, その值を用いて極限 安定解析をする方法 ${ }^{25) ~ 27) な と ゙ か ゙ あ る . ~}$

砂の動的強度の取り扱いの考え方にも種々のもの がある27. 砂地盘は初期せん断応力によって動的強度 が異なること, 繰り返しにより強度低下が生じるこ と, ステージテストによるせん断応力履歴の影響が あることなども知られている. しかしながら, 本研 究では実務で用いられる可能性のある極限安定解析 法を意識して, それによって実験結果を検討するこ ととした.ここで使用した安定解析法は, 地震力を 水平な静的な力に置き換えると共に, 動的強度とし ては過剩間隙水圧上昇に伴う強度低下を考慮したも のである.

\section{(1) 計算条件}

ここで用いた計算方法は, 抵抗モ一メントと転倒 モーメントの大小関係から,すべり安全率を計算す る伝統的な方法であるが, 摩擦力による抵抗モーメ ントの算定に当たっては, 土塊を分割して考えるス ウェーデン法のうち, チェボタリオフが述べている 方法 ${ }^{28)}$ をいている. 本方法は, 港湾施設の技術上の 基準に取り入れられているものである1). また, 安定 計算の対象とした断面は模型の横幅を考虑し, 側壁 の外側の地盤は考虑していない.

計算に使用した地震力は, 各加振段階で得られた 加速度の最大值をそのまま静的な水平力に置き換え た. このとき, 深さ方向の地震力の違いを考慮する ため，図-7に示すようにA〜F層まで深さ方向に6層に 分割し, それぞれの加振段階の地震力を決定した. 同様に，間隙水圧の発生に伴うせん断抵抗の低下を 考慮するため, 水面下の地盤も図のように分割し, それぞれに間隙水圧の值を設定した．表-3,4は計算に 使用した地震力と間隙水圧の一覧表である. 
表-4 安定解析に用いた過剰間隙水圧一覧表

\begin{tabular}{|c|c|c|c|c|c|c|c|}
\hline ケース & 加振段階 & $\mathrm{A}$ 層 & $\mathrm{B}$ 層 & $\mathrm{C}$ 層 & $\mathrm{D}$ 層 & $\mathrm{E}$ 層 & $\mathrm{F}$ 層 \\
\hline \multirow{5}{*}{1} & 1 & 0.03 & 0.03 & 0.03 & 0.03 & 0.03 & 0.03 \\
\cline { 2 - 8 } & 2 & 0.14 & 0.12 & 0.10 & 0.11 & 0.11 & 0.11 \\
\cline { 2 - 8 } & 3 & 0.24 & 0.19 & 0.14 & 0.19 & 0.18 & 0.17 \\
\cline { 2 - 8 } & 4 & 0.27 & 0.25 & 0.20 & 0.16 & 0.28 & 0.36 \\
\hline \multirow{4}{*}{2} & 1 & 0.08 & 0.07 & 0.05 & 0.05 & 0.05 & 0.05 \\
\cline { 2 - 8 } & 2 & 0.24 & 0.19 & 0.13 & 0.12 & 0.15 & 0.12 \\
\cline { 2 - 8 } & 3 & 0.23 & 0.21 & 0.15 & 0.16 & 0.17 & 0.16 \\
\hline 3 & 1 & 0.03 & 0.03 & 0.03 & 0.02 & 0.02 & 0.02 \\
\cline { 2 - 8 } & 2 & 0.06 & 0.05 & 0.05 & 0.05 & 0.05 & 0.04 \\
\cline { 2 - 7 } & 3 & 0.10 & 0.10 & 0.10 & 0.12 & 0.13 & 0.09 \\
\cline { 2 - 7 } & 4 & 0.31 & 0.26 & 0.21 & 0.18 & 0.24 & 0.23 \\
\cline { 2 - 7 } & 5 & 0.33 & 0.29 & 0.27 & 0.27 & 0.25 & 0.27 \\
\hline
\end{tabular}

a) ケース 1
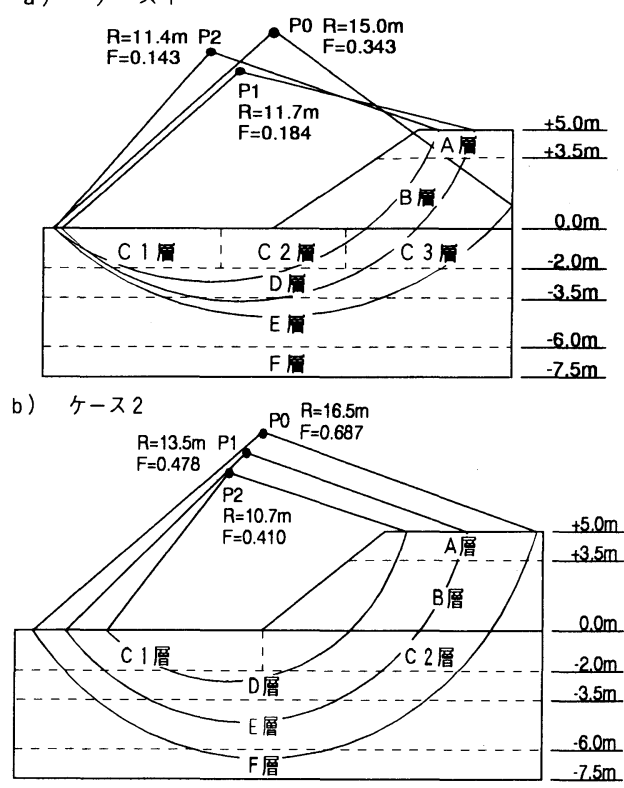

c) $ケ-\pi 3$

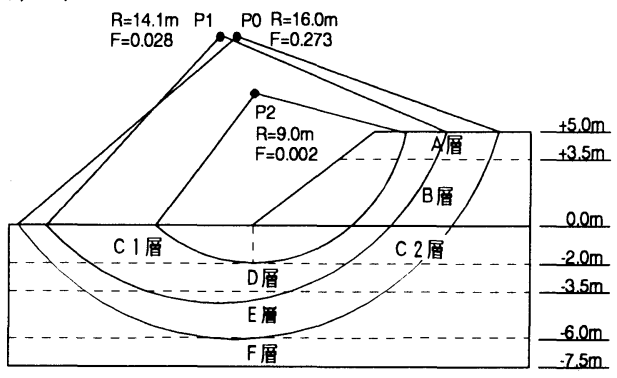

図-7 安定解析に用いた円弧の中心と半径および設定し た地震力と過剩間隙水圧の領域分割

安定計算に使用した土の強度は，地震の最中は非 排水状態であると考え, 内部摩擦角の変化は無いと 考えた. したがって, せん断強度の低下は内部摩擦
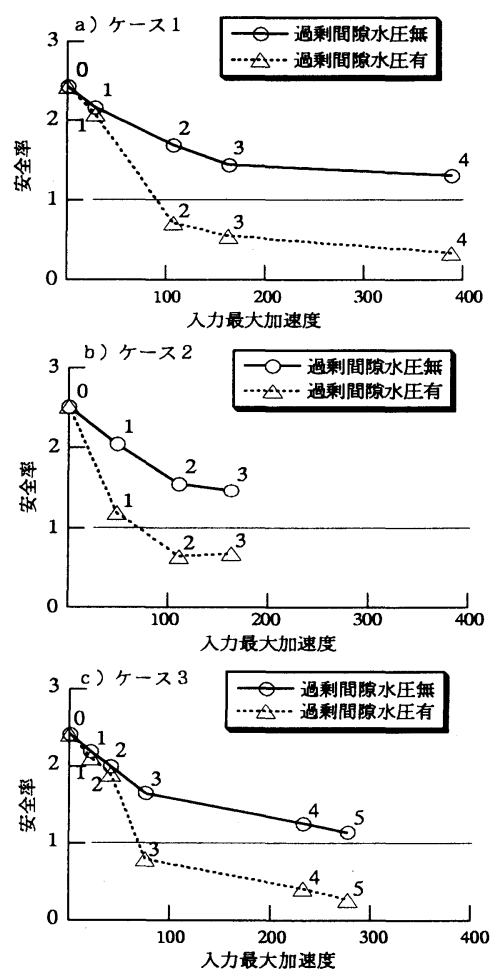

図-8 P0の円弧に対する各加振段階毎の安全率

角が見かけ上低下するのではなく，有効鉛直応力の 低下を持って表している，なお，比較のため間隙水 圧の発生を考虑しない計算屯実施した。

\section{（2）すべり面を固定した安定計算結果}

まず, 図-5に示したように実験の結果から得られ た残留変形が生じた境界面を滑り面と考え計算を実 施した. 図-8は，この計算による安全率と入力最大 加速度の関係を示したものである. 図中の数字は各 ケースの加振段階を示しており，0は常時の計算を意 味する. 安全率が1を切る加振レベルはいずれのケー スも図-6で残留変形が発生し始める加振段階に対応 している. 一方, 過剩間隙水圧を考慮しない計算で は安全率が1より大きく，実験結果に対応しない．

以上のように, 静的な安定計算法でも, 実験結果 を定性的に説明できたのは，加振レベルを上げるこ とによる地震力の増加よりも, むしろ過剩間隙水圧 が発生することによるせん断抵抗の低下が破壊現象 に支配的だったためとも考えられる.

\section{(3) すべり面を変化させた安定計算結果}

地震時の安定解析を実施する場合, 力を伝える土 の強度に限界があることから, 実際の安全率は1を下 回らないと考えられている23).これは, 安全率が1に 

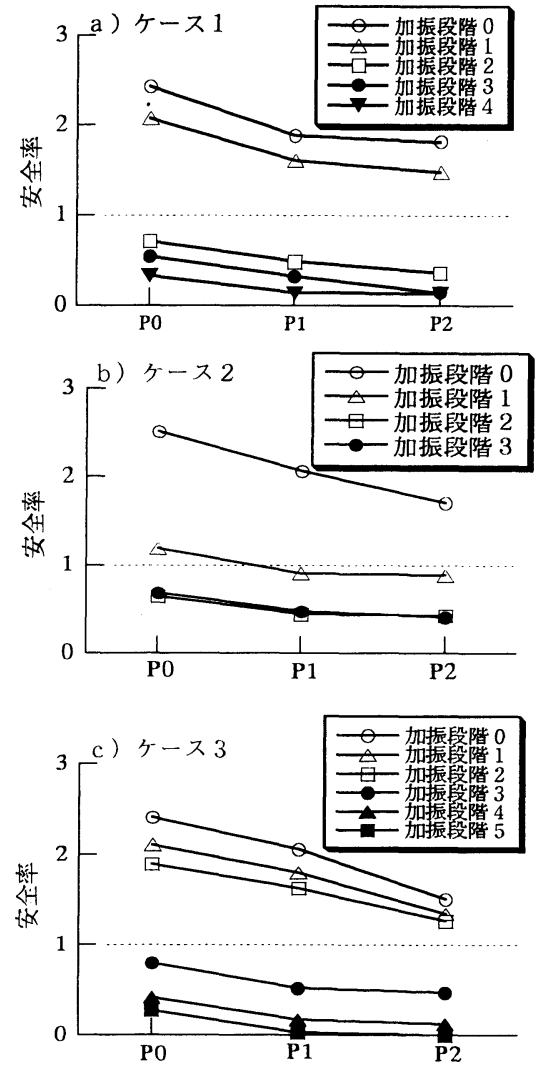

図-9 すべり面位置と安全率の関係

なった時点で変形が生じ，力の釣り合いを保ちなが ら変形が進むと考えられるからである。したがっ て, 実際の変形の進行過程は円弧状の土塊が剛体的 に滑るのではなく, 安全率が1を切るようなところか ら順番に変形が進んでいくと考えられる．実験の結 果をみても，図-5に示したように変形のべクトル は, 土塊の剛体的な変形モードとは異なるものであ る. 図のような変形は, 各加振段階で弱いところか ら順に大きく変形して行ったと考えると説明できる 亡考えられる，そこでまず，円弧の中心座標とその 半径をパラメータにした各加振段階ごとの計算を網 羅的に実施し（概ね200ケース以上），個々の安全率 を求めた. その結果, 円弧の半径を固定して中心座 標のみを単調に変えた計算, あるいは円弧の中心座 標を固定して半径のみを変化させた計算における安 全率の系統的な変化は限られた領域に見られただけ であった. しかしながら，図-5に示した円弧よりも 上方に来る円弧の中に, 図-5に示した円弧より小さ な安全率を与える円弧が存在することを確認した. 図-7は，それぞれのケースについてそのような円弧 のうちの2例 (中心座標がP1,P2で与えられる円弧)
を図示したものである.なお，図-7中で円弧の中心 がP0の円弧は図-5に示した円弧に対応し，Fは最終加 振段階で求められた安全率を示している.

図-9は，図-7に示した各ケースごとの安全率と円弧 の位置との関係を示したものである. 図から，円弧 の切る線を上方に持って行った場合 $(\mathrm{P} 1, \mathrm{P} 2)$ ， その 安全率は図-5に示した円弧（P0）よりも小さくな る. 円弧で囲まれた土塊に作用する地震力が大きい ほど, すべり面上のせん断抵抗が小さいほど安全率 が小さくなるのは自明である. またその変形量も, 計算法が同じであるならば, 安全率が小さいほど大 きいと考えられる. したがって, 安全率の大小に着 目すれば，図-5で示した円弧より上方に，よりすべ りやすい面が存在し, 変形も上方ほど大きいと考え ることができる．このように安全率が1を切るような いくつかの円弧を考え, 安全率の大小に応じて変形 量が決まったと考えると, 破壊形態や変形量の大き さは実験結果と矛盾しない，以上の結果は加速度応 答や間隙水圧応答を考慮した静的計算法の一定の妥 当性を示すものと考えられる.

\section{5. 結論}

本研究では, 遠心力振動実験により, 砂地盤上の 盛土斜面の地震時安定性を検討した. 結論を要約す ると以下のとおりである.

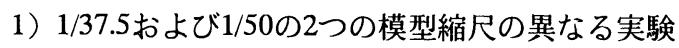
を実施し，同一規模の実物に実験結果を換算し比較 した. その結果, 加速度応答, 間隙水圧応答, 残留 変形量ともに整合するものであった. 今回対象とし た問題について遠心力場の相似則の適用性が1/37.5 1/50の範囲で確認できた.

2) 正弦波 $2 \mathrm{~Hz} 20$ 波亡地震波（八戸波）の残留変形 量を比較した. 同じ残留変形量を生じさせるために は, 地震波の最大加速度を正弦波の約 2 倍亡する必要 があることがわかった.

3）飽和砂地盤上の斜面の残留変形が生じる境界面 は，ほぼ円形すべり的な破壊面となった。 しかしな がら円弧で囲まれた土塊は剛体的に回転変形するの ではなく，上方ほど大きな変形を示すような流動的 な変形モードとなった.

4）飽和地盤上の盛土に関して実験で得られた応答 加速度分布及び間隙水圧分布を考慮した円形すべり 安定計算を実施したところ, 実験結果を説明するこ とができた. したがって, 実際の地盤でも, 盛土や 地盤の地震応答や過㮃間隙水圧の発生量をうまく予 測すれば，この值を用いた静的計算で斜面の地震時 安定性の照查が可能亡考えられる. 


\section{参考文献}

1）港湾の施設の技術上の基準・同解説,(社)日本港湾協会, 6 章斜面の安定, pp.424-426, 1990年.

2) 佐々木康, 谷口栄一, 松尾修, 館山悟 : 土構造物の地震 被害事例解析, 土木研究所資料第1576号, 1980年.

3）地震による盛土の被災・復旧事例調査報告, 土木研究所 資料第2716号, 1989年.

4) 那須誠 : 地震被害と地盤構造の関係に関する研究, $158 \mathrm{p}$, 1993.

5）1993年釧路沖地震震害調査報告, (社) 土木学会震害調 査シリーズ2,1994年.

6) 西川純一, 高橋光昭, 山下彰司 : 1993 年北海道南西沖 地震における道路・鉄道・河川堤防の被害, 土と基礎, Vol.41, No.11,pp.11-16, 1993年.

7) 西川純一, 鎌田拓司, 加治昌秀 : 1994年北海道東方沖 地震における道路・鉄道・河川堤防の被害, 土と基礎, Vol.43, No.4,pp.7-10, 1994年.

8）風間基樹,田中祐人，輿石逸樹：1994年三陸はるか沖 地震における港湾・鉄道施設の被害, 土と基礎, Vol.43, No.11, pp.21-26, 1995年.

9）土木学会 : 阪神大震災震害調査緊急報告会資料, 1995年.

10)土木学会阪神大震災震災調査第二次報告会資料, 1995年.

11)Uwabe,T., Kitazawa, S. \& Higaki, N.: Shaking table tests and circular arc analysis for large models of embankments on saturated sand layers, Soils and Foundations, Vol.26, No.4, pp.1-15, 1986.

12)古賀泰之, 松尾修, 唐澤安秋, 武藤正人 : 盛土・斜面の 簡易動的安定解析法に関する実験的研究報告書（第 1 報），土木研究所資料第2542号, 1988年.

13)Koseki, J., Koga, Y. \& Takahashi, A. : Liquefaction of sandy ground and settlement of embankment, Proc. of Centrifuge 94,pp.215-220, 1994.

14)Astaneh, S.M., Ko,H.-Y. \& Sture, S. : Assessment of earthquake effects on soil embankments, Proc. of Centrifuge 94, pp.221-226, 1994.

15)Muraleetharan, K.K., Arulmoli, K. \& Jagannath, S.V. : Varidation of a computer code for the analysis of dike retaining structures, Proc. of Centrifuge 94, pp.203-208, 1994.
16)末政直晃, 片田敏行, 豊澤康男, 玉手聡, 堀井宣幸・岸 田裕 : 飽和砂地盤上の盛土の遠心模型実験, 第 9 回日本 地震工学シンポジウム論文集, Vol.1, pp.889-894, 1994 年.

17)例えば, 講座「遠心模型実験」, 土と基礎, Vol.35, No.11 〜 Vol.36, No.8, 1987〜1988年.

18)Terashi,M :Developmeut of PHRI Geotechnical Ceutrifuge and Its Application, Report of PHRI, Vol.24, No.3, pp.73 $\sim 122,1985$.

19)稲富隆昌, 風間基樹, 野田節男, 土田 肇 : 港湾技術研 究所における遠心力載荷模型振動実験, 天然資源の開発 利用に関する日米会議, 耐風・耐震構造専門部会第1回 合同部会会議録, pp.181 192，1989年5月.

20)風間基樹, 稲富隆昌 : 遠心力載荷実験手法の振動実験へ の適用について,土木学会論文集, No.477/I-25, pp.83-92, 1993年10月.

21)鈴木輝一，鄭京哲，大保直人，林寛 : 鋼矢板リングを用 いた液状化対策工法の評価検討, 土と基礎, Vol.43, No.7, pp.31-33, 1994年.

22)藤井斎昭 : 遠心力載荷装置による浅基礎の支持力機構に 関する研究, 東京工業大学学位請求論文, 1976年.

23)土質工学会入門シリーズ 14 , 斜面の安定解析入門, 1989 年.

24)例えば,土質工学会編, 土質基礎工学ライブラリー 24 , 土 質地震工学, 1983年.

25)那須誠, 須長誠, 藤沢一, 匹本慶一 : 日本海中部地震の 際の盛土の地震時挙動-無被害盛土の安定解析-, 鉄道技 術研究所速報, No.A-85-114,119p, 1985年6月.

26)那須誠, 藤沢一, 匹本慶一：日本海中部地震による被害 盛土の安定解析, 鉄道技術研究所速報, No.A-86-14, 1986年7月, 83p.

27)古賀泰之，松尾修 : 地震時斜面安定解析に用いる土の強 度に関する考察, 土と基礎, Vol.36, No.5, pp.37-42, 1988 年.

28)石井靖丸訳 : チェボタリオフの土質工学, 技法堂, 1957年.

(1995.10.9 受付)

\title{
STABILITY OF EMBANKMENT ON LIQUEFIABLE SAND LAYERS IN CENTRIFUGE SHAKING TABLE TESTS
}

\section{Motoki KAZAMA, Takamasa INATOMI, Eiji IIZUKA and Takayuki NAGAYOSHI}

\begin{abstract}
The paper reports the results of centrifuge shaking table tests to study the stability of embankment on liquefiable sand layers during the earthquakes. On basis of the results of 1/37.5 and 1/50 scaled models, the residual deformation of embankments subjected to both sinusoidal wave and earthquake motion was studied. The conclusions obtained from this study are as follows: (1) The residual deformations of different scaled model converted to prototype scale were well consistent. (2) Liquefaction of base ground considerably affected the stability of embankments. The soil mass enclosed by the circular arc did not behave like a rigid body, but like a flow type failure. (3) A method of circular arc analysis taking into account the seismic force and the excess pore pressure gave a reasonable explanation of the test results.
\end{abstract}

